\title{
STRIATED GROUND IN THE VENEZUELAN ANDES
}

\author{
By Carlos Schubert \\ (Departamento de Ecología, Instituto Venezolano de Investigaciones Científicas, Caracas ror, \\ Venezuela)
}

\begin{abstract}
Striated ground was found above $3600 \mathrm{~m}$ elevation in the Páramo de La Culata, Pico Espejo and Pico Bolivar areas of the central Venezuelan Andes. This ground, formed by nocturnal freezing and diurnal thawing of the contained water, consisted of aligned lumps of fine to coarse sand, separated by small discontinuous channels ( $1-3 \mathrm{~cm}$ wide). Sorting was observed in the form of pebble-rich and pebble-poor zones. Striated ground in the process of formation showed that needle ice filled the channels before thawing. Lack of sorting is an indication of very recent formation, probably the previous night. The orientation of the striae is compared with the wind direction. This indicates that the formation of needle ice in the ground reflects the direction of the freezing wind, producing striae orientated in that direction, thus supporting Troll's (1944) original observations.

RÉsumÉ. Sols striés dans les Andes Vénézueliennes. Des sols striés ont été trouvés à $3600 \mathrm{~m}$ d'altitude dans les zones du Páramo de La Culata, du Pico Espejar et du Pico Bolívar dans les Andes Vénézueliennes Centrales. Ces sols formés par le gel nocturne et la fonte diurne de l'eau incluse, consiste en bourrelets alignés de stable fin à grossier, séparés par des petites dépressions discontinues ( 1 a $3 \mathrm{~cm}$ de large). On observe un tri sous la forme de zone riches en cailloux, et de zones pauvres en cailloux. Des sols striés en cours de formation montrent que les aiguilles de glace remplissaient les dépressions avant la fusion. Le manque de tri est l'indice d'une formation très récente, probablement au cours de la nuit précédente. L'orientation des stries est mise en rapport avec la direction du vent. Ceci indique que la formation d'aiguilles de glace au sol reflète la direction du vent provoquant le gel, qui produit des stries orientées dans sa direction, confirmant donc les observations originales de Troll (1944).

Zusammenfassung. Streifenboden in den venezolanischen Anden. Streifenböden wurden in über $3600 \mathrm{~m}$ Meereshöhe in den Gebieten von Páramo de La Culata, Pico Espejo und Pico Bolívar (zentrale venezolanische Anden) gefunden. Diese Böden, die durch nächtliches Gefrieren des Bodenwassers und Tauen während des Tages entstanden sind, bestehen aus ausgerichteten Klumpen von feinem bis grobem Sand, die durch schmale, unterbrochene Rinnen getrennt sind ( 1 bis $3 \mathrm{~cm}$ breit). Eine Sortierung des Materials fand in der Form der Ausbildung kieselreicher und kieselarmer Zonen statt. Während des Entstehungsvorganges der Streifenböden zeigte sich, dass die Rinnen vor dem Auftauen mit Nadeleis gefüllt waren. Das Fehlen einer Sortierung ist ein Beweis für eine sehr frische Bildung, vermutlich in der vorhergehenden Nacht. Die Orientierung der Streifen wurde mit der Windrichtung verglichen. Es ergab sich, eine Übereinstimmung zwischen der Richtung der Nadeleisformationen und der des kühlenden Windes, was Streifen in dieser Richtung zur Folge hat. Die ursprünglichen Beobachtungen von Troll (1944) werden damit bestätigt.
\end{abstract}

\section{INTRODUCTION}

During field work on glacial geology and neoglacial effects in the Venezuelan Andes (Schubert, 1970, 1972, in press), the author found numerous examples of striated ground (Fig. I), all of them above $3600 \mathrm{~m}$ elevation. The best examples were observed in Páramo de La Culata, north of the city of Mérida, and in the Pico Espejo and Pico Bolívar areas, south-east of that city. The first locality is a broad highland valley with an average elevation of about 4 ooo $\mathrm{m}$, surrounded by mountain ranges reaching $4700 \mathrm{~m}$. The two other localities represent the highest areas of the Sierra Nevada de Mérida, reaching elevations of $5000 \mathrm{~m}$. Shrinking remnants of late Pleistocene glaciers still exist on Pico Bolívar and other high peaks of the sierra. Both areas are located in the central Venezuelan Andes and are underlain by rocks of Precambrian (?) Sierra Nevada facies (Kovisars, I971 ; Shagam, I972), consisting of gneisses, schists and amphibolites, intruded by granitic rocks. Striated ground in tropical mountain areas has been previously described by Troll (r944), Lliboutry (1955, I96r) and Lorenzo (ig69), among others.

\section{DESGRIPTION OF THE STRIATED GROUND}

The Páramo de La Culata area is especially rich in striated ground. Figure 2 shows a typical example of this periglacial feature in that area. The areas of striated ground generally measure less than $\mathrm{I} \mathrm{m}$ across and are found on almost all flat or nearly flat ground surfaces. 


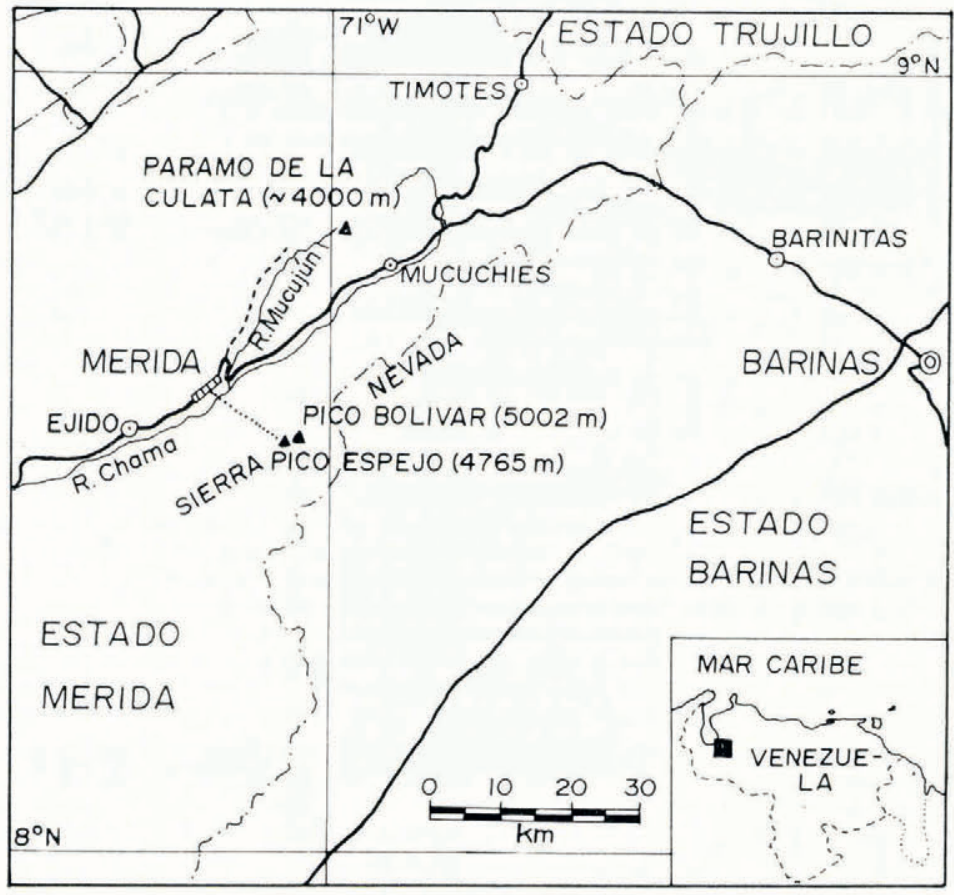

Fig. I. Index map.

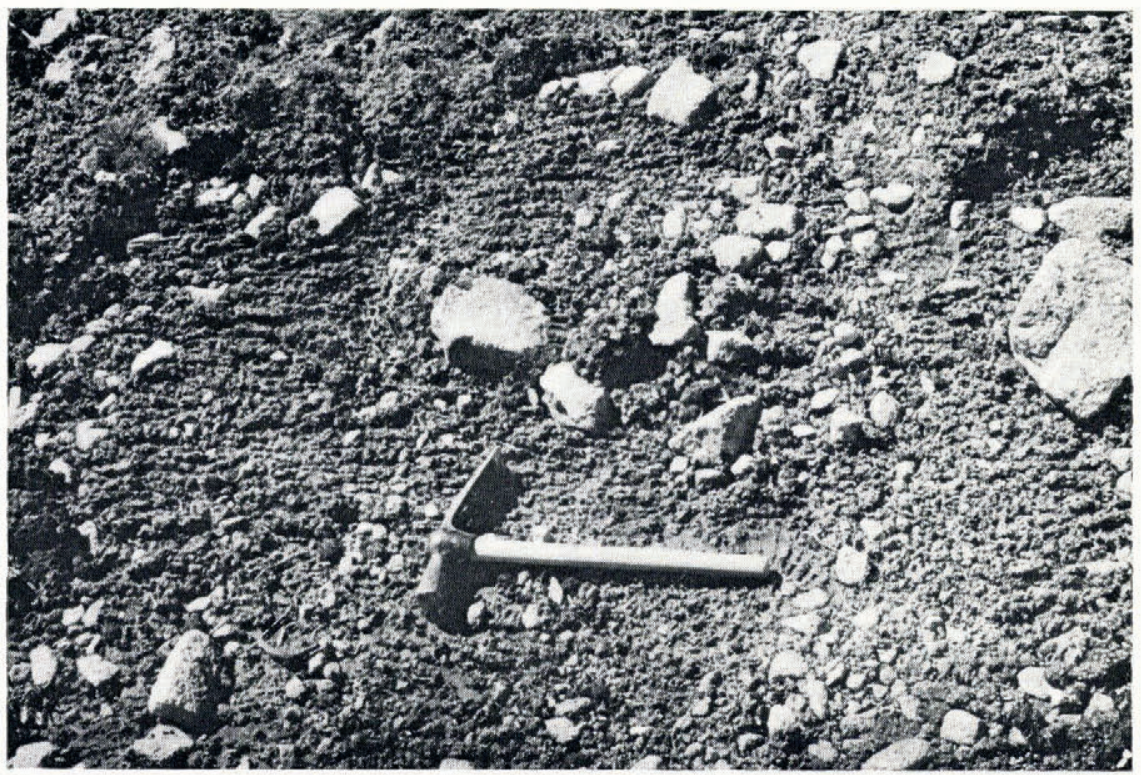

Fig. 2. Striated ground in Páramo de La Culata (length of hammer is $35 \mathrm{~cm}$ ). Note the low degree of sorting into pebble-rich and pebble-poor zones. 
Striated ground was observed on the shores of glacial lakes, between large erratic boulders, on top of morainic deposits and, in general, wherever there was an open surface of sandy ground. The high degree of sorting described by Troll (I944, p. 586, fig. I 5 ) in his classic description of patterned ground in tropical mountains was not observed. However, in Figure 2 one can distinguish pebble-rich and pebble-poor zones, which are evidence of a low degree of sorting. In this area, frozen striated ground was not observed but it is evident, by comparing Figure 2 (this paper) with figures I 3, I 5 and 2 I of Troll (I944) and with figure 2 of Lorenzo (1969), that one is dealing with similar features, i.e. striated ground. In Páramo de La Culata it was found to consist of aligned lumps of fine to coarse sand, separated by narrow channels about $\mathrm{I}-3 \mathrm{~cm}$ wide. These channels were not continuous, generally measuring no more than IO-20 cm in length, but they were parallel to each other. This is probably a reflection of the parallelism of the bands of needle ice which filled them (Troll, i944, fig. I4).

Table I shows the scant climatic data from areas adjacent to Páramo de La Culata. Only two stations (Valle Grande and Páramo de La Culata) are located within the Río Mucujún valley, whose upper part is Páramo de La Culata. The difference in rainfall between this valley and that of the Río Chama (in the higher part of which all of the other stations are located) is evident. Rainfall in the Río Mucujún valley is roughly double that of the Río

Table I. Rainfall data (Monthly averages in mm) at localities near Páramo de La Culata (Division de Hidrometeorología, Dirección de Obras Hidráulicas, Ministerio de Obras Públicas, Venezuela)

\begin{tabular}{|c|c|c|c|c|c|c|c|c|c|c|c|c|c|}
\hline & Jan & $\mathrm{Feb}$ & Mar & $A p r$ & May & June & July & Aug & Sept & Oct & Nov & $D e c$ & Year \\
\hline $\begin{array}{l}\text { Valle Grande } \\
(c .2500 \mathrm{~m})(196 \mathrm{I}-70)\end{array}$ & 59.8 & $39 \cdot 7$ & 57.0 & 275.1 & $258 . \mathrm{I}$ & 105.6 & 107.2 & I 43.8 & $154 \cdot 3$ & $243 \cdot 4$ & I 39.2 & 70.6 & I 652.0 \\
\hline $\begin{array}{l}\text { Páramo de La Culata } \\
(c .3 \text { ooo m) (196 } 1-70)\end{array}$ & $35 \cdot 7$ & 22.5 & $44 \cdot 5$ & 180.3 & I 62.2 & IOI. 5 & $75 \cdot 7$ & IO9.3 & 118.0 & 173.4 & I 29.0 & $34 \cdot 7$ & I 186.9 \\
\hline $\begin{array}{l}\text { Mucuchíes } \\
(3 \text { ooo } \mathrm{m}) \quad(\text { (1953-70) }\end{array}$ & 5.6 & 6.1 & I 3.2 & 71.0 & 87.8 & 68.3 & 66. I & 64.2 & $71 \cdot 3$ & 78.0 & $34 \cdot 3$ & $9 \cdot 9$ & 575.9 \\
\hline $\begin{array}{l}\text { San Rafael de Mucuchíes } \\
(3140 \mathrm{~m}) \\
(\text { (1949-70) }\end{array}$ & 6.5 & $4 \cdot 3$ & I 3.4 & 66.7 & 92.0 & 89.2 & $9^{1} \cdot 1$ & $77 \cdot 5$ & $77 \cdot 7$ & $71 \cdot 9$ & 3 I. 6 & 8.5 & 630.5 \\
\hline $\begin{array}{l}\text { Páramo de Mucuchíes } \\
(4 \mathrm{I} 18 \mathrm{~m}) \quad\left(194^{2}-70\right)\end{array}$ & 8.5 & 8.6 & 17.9 & 69.9 & 107.2 & 1 30.6 & 143.4 & 109.7 & 80.5 & 80.3 & $3^{8.9}$ & 18.2 & 813.8 \\
\hline $\begin{array}{l}\text { Pico El Aguila } \\
(4118 \mathrm{~m}) \quad(1953-70)\end{array}$ & 8.6 & 7.8 & I 7.4 & 68. I & 103.4 & I 24.4 & 127.7 & $97 \cdot 9$ & $8_{3.4}$ & 86.5 & 54.6 & I 6.3 & $795 \cdot 9$ \\
\hline
\end{tabular}

Chama valley. Table II shows the temperatures of the last two stations of the Teleférico de Mérida (a funicular which connects the city of Mérida ( $1497 \mathrm{~m}$ ), with Pico Espejo (4 $765 \mathrm{~m}$ )). The Loma Redonda station $(4065 \mathrm{~m})$ represents the elevation of Páramo de La Culata and it is assumed that the temperatures are comparable. Note that in almost all months of the year the minimum absolute temperature is below $0^{\circ} \mathrm{C}$. Figure 3 shows the average diurnal variation in the air temperature at Loma Redonda. These conditions coincide with those described by Troll (I 944, p. 59I-92) for the formation of striated ground: daily freezing and thawing. The higher atmospheric humidity (and consequent higher ground humidity) in the Río Mucujún valley probably accounts for the higher frequency of occurrence of striated ground in its higher parts (as compared with adjacent areas).

In the vicinity of Pico Espejo (Fig. I), whose elevation reaches $4765 \mathrm{~m}$, striated ground in the process of formation was found. On I2 December I97 I, approximately at 8 a.m., the author observed striae in small patches of sandy ground among outcrops of gneiss and schist, which form the crest of the Sierra Nevada de Mérida. A large part of the summit was covered by frost and snow covered the flanks. Figure 4 a shows striated ground whose needle ice, which filled the channels between striae, had already melted, producing a feature similar to that in Figure 2. Figure 4b, however, shows some channels which still contain needle ice (especially on the left, just below the small snow patch). No sorting was observed in this last example; the stones and sand are mixed. On the other hand, some sorting can be observed in Figure 4a. 
This probably indicates that the striated ground of Figure $4 \mathrm{~b}$ is younger than that of Figure $4 \mathrm{a}$, possibly originating the night before. Sorting is the result of a daily repetition of the freezing and thawing process, while the formation of striae could probably be accomplished overnight. Further evidence for this was found during the latter part of February 1973, in Páramo Mucumposito, just north of Páramo de La Culata (Fig. I). Here, an easily accessible locality of striated ground is located at an elevation of 4 roo m. At ro a.m. on 27 February, there were several surfaces of striated ground with rows of needle ice orientated parallel to the prevailing

Table II. Some climatic data (Monthly averages) at the last two stations of the Teleferico de Mérida i $970-71$ (Informe Climatológico, Servicio de Meteorología, Fuerza Aérea Venezolana)

Loma Redonda (4 $065 \mathrm{~m}$ )

Average temperature $\left({ }^{\circ} \mathrm{C}\right)$

Maximum absolute temperature $\left({ }^{\circ} \mathrm{C}\right)$

Minimum absolute temperature $\left({ }^{\circ} \mathrm{C}\right)$

Total rainfall $(\mathrm{mm})$

Average temperature $\left({ }^{\circ} \mathrm{C}\right)$

Maximum absolute temperature $\left({ }^{\circ} \mathrm{C}\right)$

Minimum absolute temperature $\left({ }^{\circ} \mathrm{C}\right)$

Total rainfall $(\mathrm{mm})$

Pico Espejo (4 $765 \mathrm{~m})$

Average temperature $\left({ }^{\circ} \mathrm{C}\right)$

Maximum absolute temperature $\left({ }^{\circ} \mathrm{C}\right)$

Minimum absolute temperature $\left({ }^{\circ} \mathrm{C}\right)$

Total rainfall $(\mathrm{mm})$

Average temperature $\left({ }^{\circ} \mathrm{C}\right)$

Maximum absolute temperature $\left({ }^{\circ} \mathrm{C}\right)$

Minimum absolute temperature $\left({ }^{\circ} \mathrm{C}\right)$

Total rainfall $(\mathrm{mm})$

$\begin{array}{cc}\text { Jan } & \text { Feb } \\ 2.6 & 3.0 \\ 9.7 & 9 \cdot 9 \\ 3.6 & 0.1 \\ 21 & 38 \\ \text { July } & \text { Aug } \\ 1.4 & 1.3 \\ 6.8 & 6.0 \\ -1.9 & -2.5 \\ 182 & 197 \\ \text { Jan } & \text { Feb } \\ 0.0 & -0.2 \\ 8.0 & 8.7 \\ -4.4 & -5.4 \\ 27 & 10 \\ \text { July } & \text { Aug } \\ -1.9 & -1.7 \\ 6.0 & 2.4 \\ -3.2 & -4.0 \\ 129 & 171\end{array}$

$$
\begin{gathered}
A p r \\
3.8 \\
7.7 \\
0.4 \\
107 \\
O c t \\
2.0 \\
5.8 \\
-1.0 \\
202 \\
A p r \\
-0.1 \\
8.9 \\
-4.6 \\
23 \\
O c t \\
0.8
\end{gathered}
$$$$
-1.7
$$$$
3 \cdot 7
$$$$
\begin{array}{r}
-5 \\
14
\end{array}
$$

$$
\begin{gathered}
\text { May } \\
4.2 \\
9.1 \\
0.9 \\
231 \\
\text { Nov } \\
2.0 \\
6.0 \\
-1.3 \\
96 \\
\text { May } \\
-0.6 \\
4.5 \\
-3.0 \\
113 \\
\text { Nov } \\
0.6 \\
6.3 \\
-2.7 \\
105
\end{gathered}
$$

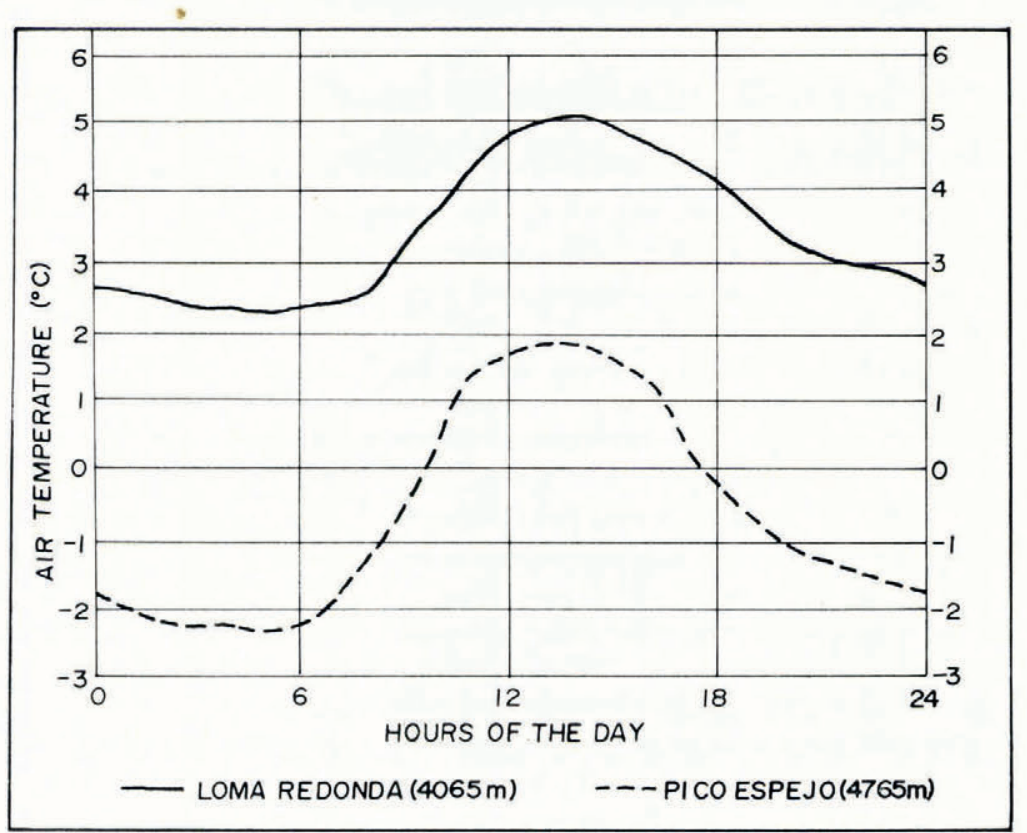

Fig. 3. Daily average variation in the air temperature $(1970-7 I)$ in the last two stations of the Teleférico de Mérida (from a report by Servicio de Meteorología, Fuerzas Aéreas Venezolanas). 


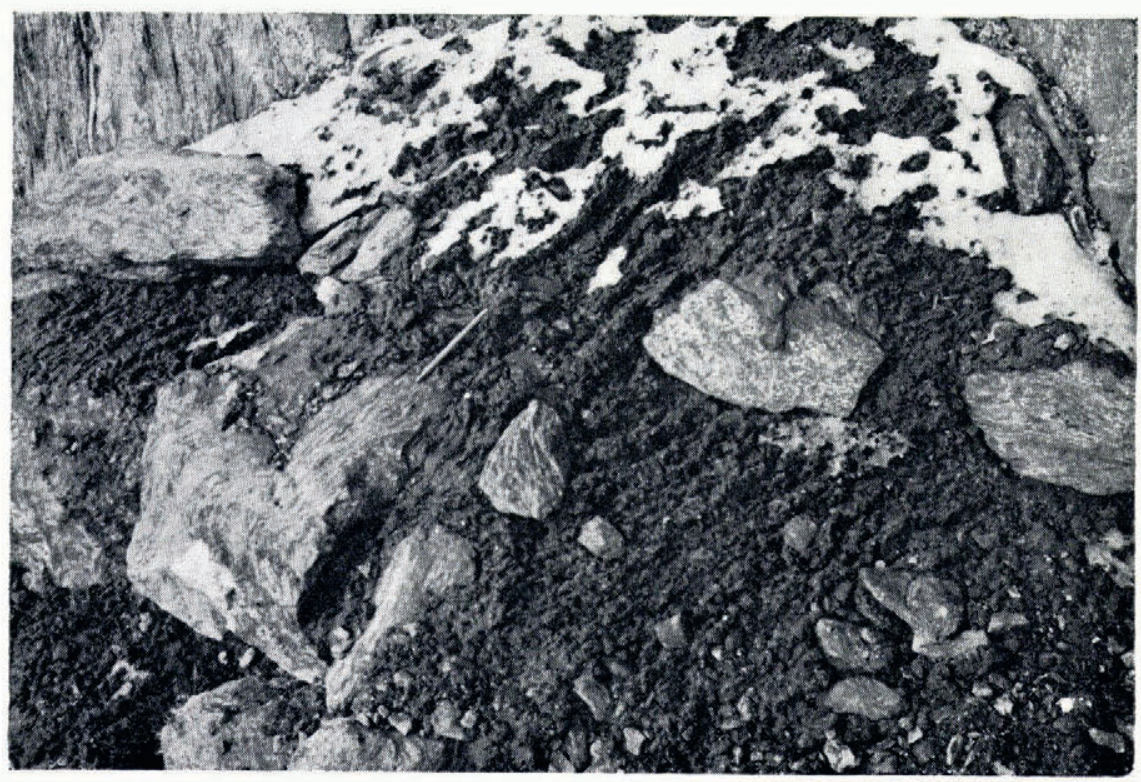

(a)

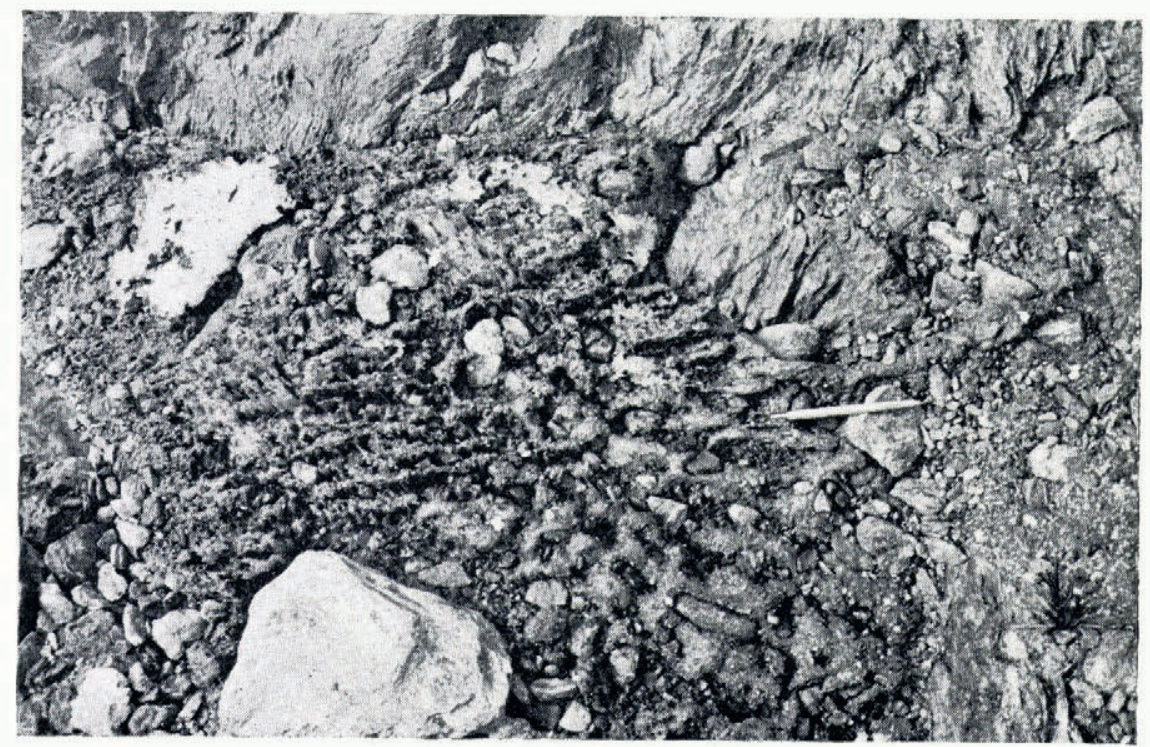

(b)

Fig. 4. (a) Striated ground in the vicinity of Pico Espejo $(4765 \mathrm{~m})$. Length of pencil is $14 \mathrm{~cm}$. (b) Striated ground with channels filled with needle ice; in the vicinity of Pico Espejo. Length of pencil is $14 \mathrm{~cm}$. 
wind direction $\left(305^{\circ}\right)$. The ice needles were $4-5 \mathrm{~cm}$ long. In one instance, where the needle ice was produced within pebbly ground, a very clear sorting was observed, the pebbles lying on top of the ice needles, and the sand and silt underneath, filling the interstices or forming the base for the needles. At 3 p.m. of the same day, the locality was revisited and all orientation, striation and sorting had disappeared due to melting of the ice. On the next day, 28 February, at 9 a.m., the locality was again visited and striation parallel to the wind direction had formed again, similar to that of the previous morning. These data are partially in agreement with the observations of Troll (1944), Corte (1963) and Philberth (1964), who estimated that at least a few days or weeks are necessary for an effective sorting of material to take place by freezing and thawing. This sorting eventually produces the large-scale striae and polygons studied by those authors.

Table II and Figure 3 show the climatic data for Pico Espejo. The daily freezing and thawing of the ground is evident; the minimum absolute temperatures are well below $\mathrm{o}^{\circ} \mathrm{C}$, while the maximum absolute temperatures are well above $0^{\circ} \mathrm{C}$. Therefore, this zone has the optimum conditions for the formation of striated ground.

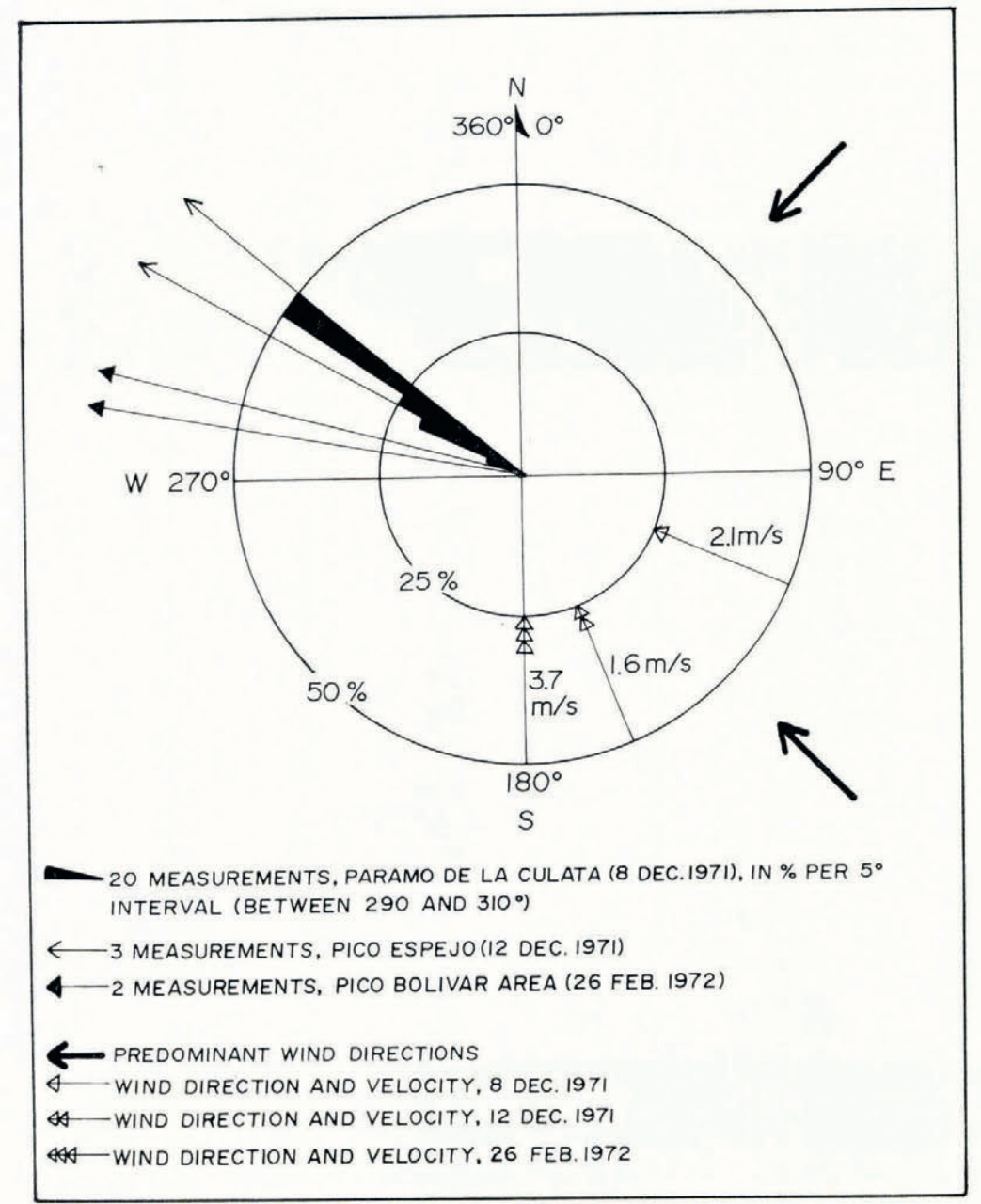

Fig. 5. Orientation of striae in ground in the Páramo de La Culala, Pico Espejo and Pico Bolivar areas; and wind directions at Pico Espejo (measured at the Observatorio Meteorológico y de Radoactividad Ambiental "Alejandro de Humboldt"). 


\section{ORIENTATION OF THE STRIATED GROUND}

The orientations of the striae in the ground were measured in all of the examples observed and they are plotted in Figure 5. Measurements in the different localities are separated because they were made on different dates. In Páramo de La Culata, where most of the measurements were made on 8 December $197 \mathrm{I}$, the striae were orientated between $290^{\circ}$ and $310^{\circ}$, although most were between $306^{\circ}$ and $310^{\circ}$. In the Pico Espejo area, on 12 December I97I the striae were orientated between $300^{\circ}$ and $310^{\circ}$; and in the Pico Bolívar area (front of Timoncito Glacier; Schubert, in press), on 26 February 1972 they were orientated between $280^{\circ}$ and $285^{\circ}$.

Wind directions on the dates mentioned above are shown in Figure 5. These represent the wind orientations at the approximate times of striae-orientation measurements. The predominant average wind directions at the Pico Espejo station are from the south-east and north-east, with a strong component from the south (personal communication from W. A. Goldbrunner, 4 April 1972).

A comparison between the orientations of the striae and the wind directions shows a fair correlation. Only the data from the Pico Bolívar area differ significantly and could be due to their location within a small cirque-like feature. The other measurements were made in open areas, where the wind was not affected by topographic features. The Pico Espejo station is located on the crest of the Sierra Nevada de Mérida and it registers the winds which pass above it. The striae in that locality were in the same situation. These data support Troll's ( 1944 , p. 585) observation that the origin of striated ground and the orientation of the striae are related to the wind direction.

An additional supporting observation was made early in the morning of 27 February 1972. On the floor of the Pico Espejo station, ice needles were deposited with their long axes parallel to the wind direction (from the south-east) and slightly inclined down-wind. This is probably the way striated ground begins to form. The water contained in the ground forms bands of needle ice which, upon thawing, form the striae in the ground.

\section{Acknowledgements}

I wish to thank the Teleférico de Mérida for providing transport and topographic maps of the Pico Espejo-Pico Bolívar area. A. W. Goldbrunner (Fuerza Aérea Venezolana, Maracay) and H. Silva (Ministerio de Obras Públicas, Caracas) kindly supplied the weather data. F. Santamaría and I. Rouse supplied copies of otherwise unavailable publications on earlier work. Special recognition is due to Haydée Hernández and Oswaldo Rodríguez (Mérida) for their help in the field. A. L. Washburn, E. Wagner, E. Medina and J. Pasquali made helpful suggestions. Finally, I should like to thank César Thielen (Mérida) for his help during all phases of my work in Mérida.

An abstract of this report was presented at the 22nd Annual Convention of the Asociación Venezolana para el Avance de la Ciencia held in Maracaibo in 1972.

MS. received 22 January 1973 and additions I3 March 1973

\section{REFERENGES}

Corte, A. E. 1963. Particle sorting by repeated freezing and thawing. Science, Vol. 142, No. 3591, p. 499-501.

Kovisars, L. 1971. Geology of a portion of the north-central Venezuelan Andes. Geological Society of America. Bulletin, Vol. 82, No. i 1, p. $3111-37$.

Lliboutry, L. A. 1955. L'origine des sols striés et polygonaux des Andes de Santiago (Chili). Comptes Rendus Hebdomadaires des Séances de l'Académie des Sciences (Paris), Tom. 240, No. 18, p. 1793-94. Lliboutry, L. A. 196r. Phénomènes cryonivaux dans les Andes de Santiago (Chili). Biuletyn Peryglacjalny, No. ıo,
p. 209-24. 
Lorenzo, J. L. 1969. Minor periglacial phenomena among the high volcanoes of Mexico. (In Péwé, T. L., ed. The periglacial environment, past and present. Montreal, McGill-Queen's University Press [and] Arctic Institute of North America, p. 16i-75.)

Philberth, K. 1964. Recherches sur les sols polygonaux et striés. Biuletyn Peryglacjalny, No. 13, p. $99^{-1} 9^{8}$.

Schubert, C. 1970. Glaciation of the Sierra de Santo Domingo, Venezuelan Andes. Quaternaria, Vol. 13, p. 225-46.

Schubert, C. 1972. Late glacial chronology in the northeastern Venezuelan Andes. International Geological Congress. Twenty-fourth session, Canada, 1972, Section 12, p. 103-09.

Schubert, C. In press. Geomorphology and glacier retreat in the Pico Bolívar area, Sierra Nevada de Mérida, Venezuela. Zeitschrift für Gletscherkunde und Glazialgeologie, Bd. 8.

Shagam, R. 1972. Geología de los Andes centrales de Venezuela. Venezuela. Ministerio de Minas e Hidrocarburos. Dirección de Geología. Boletín de Geologia, Publicación Especial No. 5, p. 935-38. [Abstract.]

Troll, G. 1944. Strukturböden, Solifluktion und Frostklimate der Erde. Geologische Rundschau, Bd. 34, Ht. 7-8, p. $545^{-694}$. 